\title{
COMPARISON OF SERVICE QUALITY, RATE, AND EASE OF USE OF MOBILE APPLICATION BETWEEN GO-JEK AND GRAB IN BATAM
}

\author{
$1^{\text {st }}$ Alieva Shavira Isfandiarto \\ Department of Applied Business Administration \\ Batam State Polytechnic \\ Batam City, Riau Island \\ alievasha24@gmail.com
}

\author{
$2^{\text {nd }}$ Rahmat Hidayat S.AB.,M.AB \\ Department of Applied Business Administration \\ Batam State Polytechnic \\ Batam City, Riau Island \\ rahmat@polibatam.ac.id
}

\begin{abstract}
This study aims to determine whether the two companies have significant differences in terms of service quality, rate, and ease of use of mobile application between GoJek and Grab in Batam. The population in this study is all people in Batam, samples taken by purposive sampling method with a total sample of 96 people. The data collection techniques in this study were done by distributing questionnaires and tested using Difference Test technique. The results of this study indicate that: there are significant differences in the three variables (service quality, rate, and ease of use of mobile application) between GoJek and Grab in Batam, which is Go-Jek is better than Grab. This is evidenced by the different test on service quality variables that indicate the Go-Jek data group has an average value more than Grab.
\end{abstract}

Keywords-Comparison, Service Quality, Rate, Mobile Application

\section{INTRODUCTION}

\section{A. Background}

Information technology at this time has a very important role in the economy of a country. The existence of this advancement in information technology makes productivity in the industrial world increase, especially in the information technology-based creative industry [1]. Its growth looks increasingly fast, as evidenced by the presence of various mobile applications in Indonesia.

The existence of this technological development provides social change in society. Various types of businesses that utilize information technology are starting to emerge, not only are social networks rife in society, but the presence of the following applications makes social change in Indonesia. Such as buying and selling online, booking hotels and others, m-banking, public services such as making passports online, paying taxes online and so on, including online transportation services that the author will discuss in this study. The existence of this online transportation service makes it easier for people to carry out activities, it also reduces people's concerns about public transportation services congestion which is a scourge for people in big cities and fear of public transportation security is answered by the existence of this online transportation application.
In addition to its practical, accessible and fast use, the existing online motorcycle taxis also offer more affordable rates than conventional motorcycle taxis. The people will certainly prefer practical transportation services at rates that are according to their wishes.

The more people are helped by their presence, the more companies offer services with the same characteristics, making competition even tighter. The online transportation business that is well known to the public today is Go-Jek and Grab. Both of these companies have a significant impact on the social life of the community, even the two companies are the main choice of the community in using online transportation services. Both of these companies are increasingly competing in providing the best service to its users.

Both have grown rapidly in terms of application development and the number of fleets for public transportation services. At this time, Go-Jek has been downloaded 50,000,000 times on the Google Play Store and App Store (iOS). Likewise with Grab, this application has been downloaded 100,000,000 times on the Google Play Store and App Store (iOS).

Formulation of the Problem

Based on this background, the formulation of the problem to be discussed in this study are as follows:

- Do the two companies have significant differences in the service quality?

- Do the two companies have significant differences in the rate?

- Do the two companies have significant differences in the ease of use of their mobile applications?

B. Significance of the Study

Here are two benefits in this study, namely:

1) Practical Significance

The benefits of this study for both companies are obtaining community satisfaction data, knowing the shortcomings in the service quality, rates, and ease of use of mobile applications both of the companies, so those companies can provide better services in the future.

2) Theoretical Significance

- The benefit of this study for readers is to know the comparison between the two companies and to be a reference for further research. 
- The benefit of this study for the writer is to add insight into the comparison of services between the two companies.

\section{REVIEW OF LITERATURE}

\section{A. Theoretical Study}

\section{1) Service}

According to [5] service is an activity that does not have physical, cannot be touched and is not visible to the eye given by one party to another party.

2) Quality

Quoted from [4], quality according to ISO 9000 is "a degree to which a set of inherent characteristics fulfills requirements" which means the degree achieved by characteristics inherent in meeting requirements. The meaning of the requirements referred to in this case is "need or expectation that is stated, generally implied or obligatory" which means the needs or expectations expressed, usually implied or mandatory.

3) Rate

According to [4], we can find prices in the service business with various designations. Universities or colleges use SPP (tuition), professional consultants use the term fee, banks use the term service charge, toll roads or transportation services use the rates, brokers use the commission, apartments use the rental, insurance uses the premium, and so on. Whereas according to [5] price is the exchange rate of an item or service, in other words, it is a product that can be exchanged on the market.

\section{4) Mobile Application}

According to [9] Mobile Application or commonly referred to as mobile apps, is a term used to describe internet applications that run on smartphones or other mobile devices.

\section{B. Conceptual Framework}

Based on the theoretical study described above, the conceptual framework is as follows:

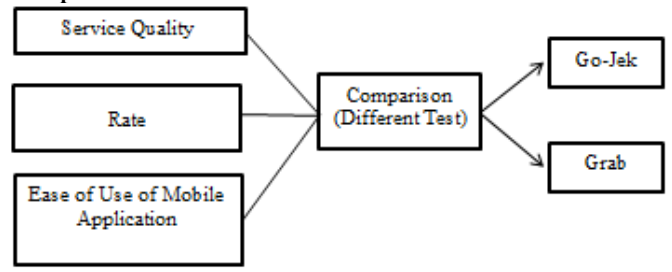

Fig. 1. Conceptual Framework

\section{Hypothesis}

The hypotheses in this study are as follows:

H1: There are significant differences in the quality of services at Go-Jek and Grab.

H2: There are significant differences in the rates on GoJek and Grab.

H3: There are significant differences in the ease of use of the mobile application on Go-Jek and Grab.

\section{METHOD OF RESEARCH}

\section{A. Research Design}

This study uses a quantitative method with a comparative approach. According to [10], Quantitative method research in the form of numbers and analysis using statistics with the help of questionnaires. Sources of data in this study through primary data obtained during the survey and secondary data obtained indirectly by studying the literature or documents [10]. Data collection techniques in this study were done by distributing questionnaires.

\section{B. Population and Sampel}

The population of this study is all the people of Batam City with a total sample of 96 people. This sample collection uses purposive sampling technique. This technique is used by researchers because of certain considerations in sampling [6].

\section{Validity and Reliability}

Validity test can be done by comparing the significance value with alpha (0.05). If the significance value is smaller than 0.05 , then the indicator of the statement on the questionnaire is valid. If the significance value is greater than 0.05 , then the indicator of the statement on the questionnaire is invalid.

According to [10] the criteria for an indicator of the statement questionnaire are declared reliable if the alpha value is greater than 0.60 .

\section{Object and Scope of Research}

The object of this research is Go-Jek and Grab in Batam city.

\section{RESULT AND DISCUSSION}

\section{A. Result and Discussion}

TABLE I.

DIFFERENCE AVERAGE BETWEEN VALUE OF SERVICE QUALITY VARIABLES GO-JEK AND GRAB DATA GROUPs

\begin{tabular}{|c|c|c|}
\hline Data Group & Average & $\begin{array}{c}\text { Average } \\
\text { Difference }\end{array}$ \\
\hline Go-Jek & 53,83 & \multirow{2}{*}{2,115} \\
\hline Grab & 51,72 & \\
\hline
\end{tabular}

H1: There are significant differences in the quality of services at Go-Jek and Grab. This is evidenced by the different test on service quality variables that indicate the Go-Jek data group has an average value of 53,83 and the Grab data group has an average value of 51,72 and the difference in the average value is 2,115 . It can be concluded that the service quality of Go-Jek is better than Grab.

TABLE II.

DIFFERENCE IN AVERAGE VALUE OF RATE VARIABLES GO-JEK

\begin{tabular}{|c|c|c|}
\hline \multicolumn{3}{|c|}{ AND GRAB DATA GROUPS } \\
\hline Data Group & Average & $\begin{array}{c}\text { Average } \\
\text { Difference }\end{array}$ \\
\hline Go-Jek & 10,16 & \multirow{2}{*}{0,646} \\
\hline Grab & 9,51 & \\
\hline
\end{tabular}

H2: There are significant differences in the rates on Go-Jek and Grab. This is evidenced by the different test on rate variable which shows the difference in the average group of Go-Jek and Grab data where Go-Jek data group is 10,16 and 
the Grab data group is 9,51 where the difference in the average value that is owned is 0,646 so it can be concluded that the rate on Go-Jek is better than Grab.

TABLE III.

DIFFERENCE IN AVERAGE VALUE OF EASE OF USE OF MOBILE APPLICATION VARIABLES GO-JEK AND GRAB DATA GROUPS

\begin{tabular}{|c|c|c|}
\hline Data Group & Average & $\begin{array}{c}\text { Average } \\
\text { Difference }\end{array}$ \\
\hline Go-Jek & 19,51 & \multirow{2}{*}{1,563} \\
\hline Grab & 17,95 & \\
\hline
\end{tabular}

Source: Data Processing Results SPSS 20 (2019)

H3: There are significant differences in the ease of use of the mobile application on Go-Jek and Grab. This is evidenced by the different test on the ease of use of the mobile application Go-Jek is also better than Grab, this is evidenced by a different test that shows the difference in the average group of Go-Jek and Grab data where Go-Jek data group is 19,51 and Grab data group is 17,95 which is the difference in the average value is equal to 1,563.

TABLE IV.

HYPOTHESIS TESTING RESULTS WITH INDEPENDENT SAMPLE T-TEST DIFFERENT TESTS INDEPENDENT SAMPLE TEST

\begin{tabular}{|c|c|c|c|c|}
\hline & \multicolumn{2}{|c|}{ Service Quality } \\
\hline & & & Equal variances assumed & $\begin{array}{c}\text { Equal variances not } \\
\text { assumed }\end{array}$ \\
\hline \multirow{2}{*}{$\begin{array}{c}\text { Levene's Test for Equality } \\
\text { of Variances }\end{array}$} & \multicolumn{2}{|l|}{$\mathrm{F}$} & .532 & \\
\hline & \multicolumn{2}{|l|}{ Sig. } & .467 & \\
\hline \multirow{7}{*}{$\begin{array}{l}\text { t-test for Equality of } \\
\text { Means }\end{array}$} & \multicolumn{2}{|l|}{$\mathbf{T}$} & 2.153 & 2.153 \\
\hline & \multicolumn{2}{|l|}{ Df } & 190 & 188.607 \\
\hline & \multicolumn{2}{|l|}{ Sig. (2-tailed) } & .033 & .033 \\
\hline & \multicolumn{2}{|l|}{ Mean Difference } & 2.115 & 2.115 \\
\hline & \multicolumn{2}{|l|}{ Std. Error Difference } & .982 & .982 \\
\hline & \multirow{2}{*}{$\begin{array}{l}\text { 95\% Confidence Interval of the } \\
\text { Difference }\end{array}$} & Lower & .177 & .177 \\
\hline & & Upper & 4.052 & 4.052 \\
\hline
\end{tabular}

Source: Data Processing Results SPSS 20 (2019)

Based on table above, it can be seen that the significance value of $\mathrm{F}$ is 0.532 which means it has a greater value than 0.05 and it can be concluded that the service quality data group between Go-Jek and Grab is homogeneous so that the $\mathrm{t}$ test uses Equal Variance Assumed (assumed the same variant). Determination of $t$ table is done first to be able to compare the value of $\mathrm{t}$ arithmetic with $\mathrm{t}$ table which can be seen from the significance of 0.05: $2=0.025$ (2-sided test) with degrees of freedom (df) $n-2$ or $96-2=94$ so that it is obtained t table value of 1.985. Furthermore, the $t$ value obtained at the Equal Variance Assumed (assumed to be the same variant) is 2.153 which means it is greater than t table of 1.985 and also at the 2-tailed Significance value of 0.033 which means it is smaller than 0.05 so it can be concluded that $\mathrm{H} 0$ rejected and $\mathrm{H} 1$ accepted which means there is a significant difference in service quality between Go-Jek and Grab.

TABLE $\mathrm{V}$.

HYPOTHESIS TESTING RESULT WITH INDEPENDENT SAMPLE T-TEST DIFFERENT TESTS INDEPENDENT SAMPLES TEST

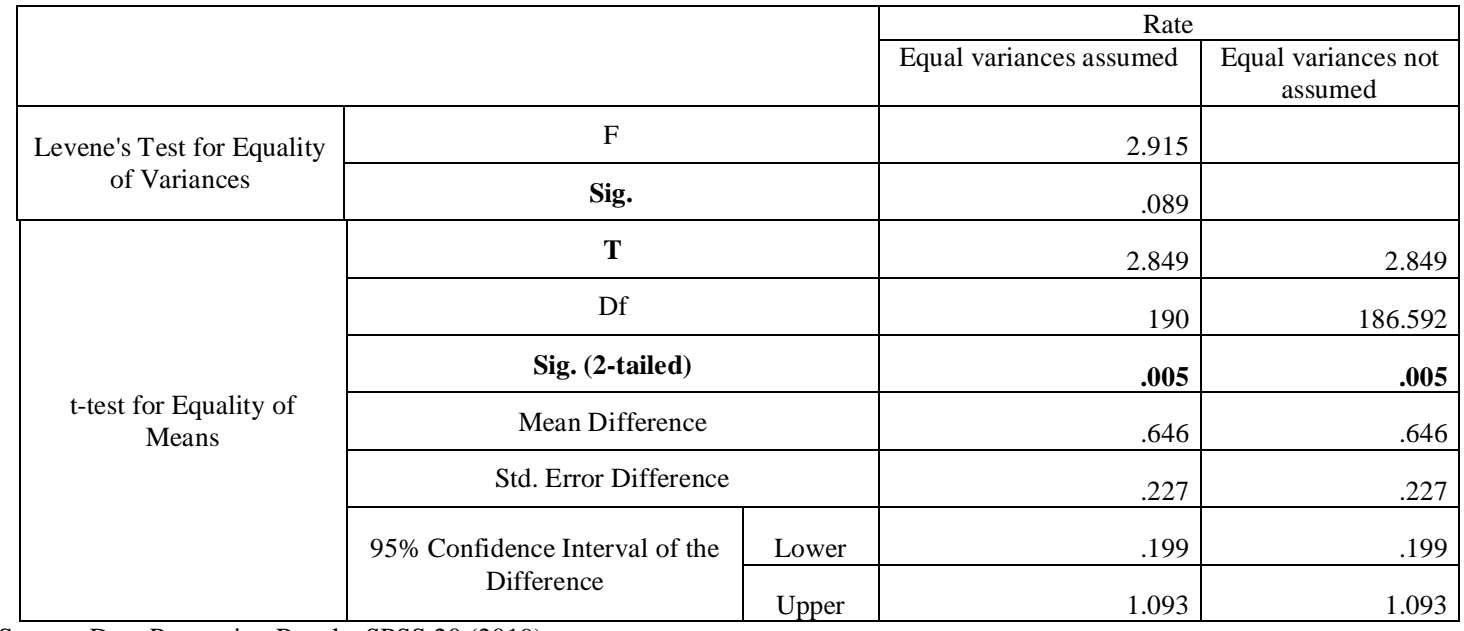

Source: Data Processing Results SPSS 20 (2019)

Based on table above, it can be seen that the significance value of $\mathrm{F}$ is 2.915 which means it has a value greater than 0.05 and it can be concluded that the service quality data group between Go-Jek and Grab is homogeneous so that the 
t test uses Equal Variance Assumed (assumed the same variant). Determination of $t$ table is done first to be able to compare the value of $\mathrm{t}$ arithmetic with $\mathrm{t}$ table which can be seen from the significance of 0.05: $2=0.025$ (2-sided test) with degrees of freedom (df) n-2 or $96-2=94$ so that it is obtained $t$ table value of 1.985. Furthermore, the $t$ value obtained at the Equal Variance Assumed (assumed to be the same variant) is 2,849 which means it is greater than $t$ table of 1.985 and also the 2-tailed Significance value of 0.005 which means it is smaller than 0.05 so it can be concluded that $\mathrm{H} 0$ rejected and $\mathrm{H} 1$ accepted which means there is a significant difference in rates between Go-Jek and Grab.

TABLE VI.

HYPOTHESIS TESTING RESULT WITH INDEPENDENT SAMPLE T-TEST DIFFERENT TESTS INDEPENDENT SAMPLES TEST

\begin{tabular}{|c|c|c|c|c|}
\hline & & & \multicolumn{2}{|c|}{ Ease of Use of Mobile Application } \\
\hline & & & Equal variances assumed & $\begin{array}{c}\text { Equal variances not } \\
\text { assumed }\end{array}$ \\
\hline \multirow{2}{*}{$\begin{array}{c}\text { Levene's Test for Equality } \\
\text { of Variances }\end{array}$} & \multicolumn{2}{|l|}{ F } & .396 & \\
\hline & \multicolumn{2}{|l|}{ Sig. } & .530 & \\
\hline & \multicolumn{2}{|l|}{$\mathrm{T}$} & 3.659 & 3.659 \\
\hline & \multicolumn{2}{|l|}{ Df } & 190 & 186.410 \\
\hline & \multicolumn{2}{|l|}{ Sig. (2-tailed) } & .000 & .000 \\
\hline $\begin{array}{l}\text { t-test for Equality of } \\
\text { Means }\end{array}$ & \multicolumn{2}{|l|}{ Mean Difference } & 1.563 & 1.563 \\
\hline & \multicolumn{2}{|l|}{ Std. Error Difference } & .427 & .427 \\
\hline & \multirow{2}{*}{$\begin{array}{l}\text { 95\% Confidence Interval of the } \\
\text { Difference }\end{array}$} & Lower & .720 & .720 \\
\hline & & Upper & 2.405 & 2.405 \\
\hline
\end{tabular}

Based on Table 4.18 above, it can be seen that the significance value of $\mathrm{F}$ is 0.396 which means it has a value greater than 0.05 and it can be concluded that the service quality data group between Go-Jek and Grab is homogeneous so that the $\mathrm{t}$ test uses Equal Variance Assumed (assumed the same variant). Determination of $t$ table is done first to be able to compare the value of $t$ arithmetic with $\mathrm{t}$ table which can be seen from the significance of 0.05: $2=0.025$ (2-sided test) with degrees of freedom (df) n-2 or $96-2=94$ so that it is obtained t table value of 1.985. Furthermore, the $t$ value obtained at the Equal Variance Assumed (assumed to be the same variant) is 3.659 which means it is greater than t table of 1.985 and also the 2-tailed Significance value of 0,000 which means it is less than 0.05 so it can be concluded that $\mathrm{H} 0$ rejected and $\mathrm{H} 1$ accepted which means there is a significant difference in the ease of use of mobile applications between Go-Jek and Grab.

\section{CONCLUSION AND SUGGESTIONS}

\section{A. Conclusion}

Based on the results of the research in the previous chapter, it can be concluded as follows:

- The most dominant respondents of Go-Jek and Grab are 67 people, users aged 16-25 years are 68 people, users work as students are 53 people, and users earning under or equal to $\mathrm{Rp} 1,500,000$,- as many as 38 people.

- There are differences in service quality, rate, and ease of use of mobile applications between Go-Jek and Grab. This is evidenced by the different tests on service quality variables that indicate the Go-Jek data group has an average value of 53.83 and the Grab data group has an average value of 51.72 where the difference in the average value is 2.115 so it can be concluded that the service quality of Go-Jek is better than Grab. Likewise with the rate variable that shows the difference in the average group of Go-Jek and Grab data where the Go-Jek data group is worth 10.16 and the Grab data group is 9.51 where the difference in the average value is 0.646 so it can be concluded that the rate on Go-Jek is better than Grab. Then, in the ease of use of the mobile application Go-Jek is also better than Grab, this is evidenced by a different test that shows the difference in the average group of Go-Jek and Grab data where the Go-Jek data group is 19.51 while the data group Grab 17.95 where the difference in the average value is 1.563 .

\section{B. Suggestions}

Based on the conclusions that have been made, the suggestions that can be given in this study are:

\section{1) For Companies}

a. Go-Jek and Grab should educate drivers not to ask users to cancel orders too often, because it will reduce the user's trust in the company, so that it can create a bad image for the company.

b. Grab should improve the non-cash payment system so that users who do not always bring cash can use the non-cash payment option.

c. Go-Jek is expected to better educate drivers to always maintain cleanliness, including helmets and jackets so that users feel comfortable when driving with drivers, because as many as $25 \%$ of respondents said that helmets and jackets used by drivers smells not good. Likewise with Grab, $30.2 \%$ of respondents stated the same thing.

d. Go-Jek should educate drivers about locations in Batam city so that drivers can come to the user's location accurately. Because some $27.1 \%$ of 
respondents said the drivers did not know the pickup location accurately. Likewise with Grab, some $22.9 \%$ of respondents said the same thing, also a number of $20.8 \%$ of respondents stated that the driver did not know the location of the destination clearly.

e. Grab should apply discipline to drivers, because as many as $24 \%$ of respondents said drivers did not arrive on time during pickup. Of course this will make the company image worse.

f. Go-Jek is expected to improve the system on the map, because a total of $20.8 \%$ of respondents said that the map display on the application is inaccurate, as well as Grab because a number of $25 \%$ of respondents stated the same thing.

2) For further Researchers

a. In further research it is better to use different variables or add other variables so that it can be used as a comparison for future research.

b. In the next research, it is expected to use other mobile application-based companies as objects, so that they can get better results.

\section{Limitations}

This study has limitations that can be described as follows:

- The companies used in this study were only Go-Jek and Grab

- The variables used in this study are only service quality, rate, and ease of use of mobile application

- The limitations since the start of this study, the data processing stage, until preparation of the study is very influential on the result of the study. If this study is carried out over a longer period of time, it is possible to obtain better results than the results of this study.

\section{REFERENCES}

[1] Chan, A., Maharani, M., \& Wulan, P. T. (2017). Comparinson of User Experience On Go-Jek and Grab Mobile APPS (Study On PT. Go-Jek and PT. Grab Indonesia Consumer In DKI Jakart). AdBispreneur

[2] Grab. (2019). Taken back from Grab Indonesia: https://www.grab.com/id/Indonesia,

[3] Go-Jek. (2019). Taken back from www.go-jek.com: https://www.gojek.com/

[4] Iskandar. (2018). Perbandingan Tarif Baru Go-Jek dan Grab. Diambil kembali dari Liputan 6 https://www.liputan6.com/tekno/read/3618943/perbandingan-tarifbaru-go-jek-dan-grab

[5] Lupiyoadi, R., \& Hamdani, A. (2011). Manajemen Pemasaran Jasa Edisi 2. Jakarta: Salemba Empat.

[6] Malau Harman. (2017). Manajemen Pemasaran Teori dan Aplikasi Pemasaran Era Tradisional Sampai Era Modernisasi Global. Bandung: Penerbit Alfabeta.

[7] Riduwan. (2016). Pengantar Statistika Sosial. Bandung: Penerbit Alfabeta

[8] Sarjono, H., \& Julianita, W. (2011). SPSS vs LISREL Sebuah Pengantar, Aplikasi untuk Riset. Jakarta: Penerbit Salemba Empat

[9] Subhadip, R., S, S., \& Sandhya, B. (2019). Service Quality Versus Service Experience: An Empirical Examination Of Ther Consequential Effects In B2B Services. Industrial Marketing Management.

[10] Sugiyono. (2014). Metode Penelitian Kuantitatif, Kualitatif dan R\&D. Bandung: CV Alfabeta.

[11] Sunyoto, D., \& Susani, F. E. (2015). Manajemen Pemasaran Jasa. Jakarta: PT Buku Seru.

[12] Turban, E. \& King D. (2012). Electronic Commerce 2012: A Managerial and Social Networks Perspective. Pearson Prentice Hall.

[13] Umiyati, \& Suyoto. (2010). Analisis Perbandingan Kepuasan Konsumen Atas Pelayanan Minimarket Indomaret Dan Alfamart Di Wilayah Dukuhwaluh. Analisis Perbandingan Kepuasan Konsumen.

[14] Utomo, H., Ananta, M. T., \& Jonemaro, E. M. (2017). Perbandingan Usabilitas Aplikasi Taxi Online Android (Grab dan Uber) Menggunakan Unfied Theory of Acceptance and Use of Technology (UTAUT). Jurnal Pengembangan Teknologi Informasi dan Ilmu Komputer, 1708-1717. 